
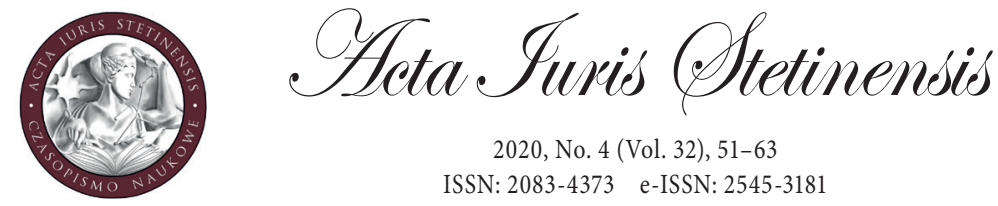

2020, No. 4 (Vol. 32), 51-63

ISSN: 2083-4373 e-ISSN: 2545-3181

DOI: $10.18276 /$ ais.2020.32-04

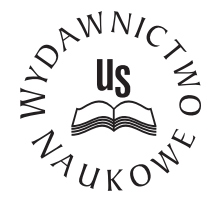

Anna Paluch

M.A.

Jagiellonian University, Poland

Faculty of Law and Administration

e-mail: anna.aleksandra.paluch@gmail.com

OPEN ACCESS

ORCID ID: 0000-0001-8488-0006

\title{
Captatoria conditio: meaning and admissibility in the light of freedom of testation. Analysis of selected legislations of Western European countries
}

\begin{abstract}
The purpose of this paper is the presentation and analysis of the testamentary disposition, present in some foreign legal orders, known by the Latin name captatoria conditio, being a particular type of conditional appointment to inheritance. The analysis includes functions of captatoria conditio and axiological doubts related to it. In the research, the examination of applicable laws and the comparative methods were used, which allowed the analysis of the form and functions of captatoria conditio and its prohibition in foreign legal orders. Conducted in such a way, the research led to the conclusion that particular systems of the law of succession include different regulations regarding the validity and effectiveness of captatoria conditio. On the basis of the analysis of the functions of captatoria conditio, this paper presents the thesis that in the case of such a disposition mortis causa there is not any excessive interference with the autonomy of the beneficiary mortis causa because he or she is always entitled to reject the inheritance. This conclusion speaks for the admissibility of captatoria conditio if the conditional appointment to inheritance is possible in a given legal system. Axiological doubts do not give arguments for the prohibition of captatoria conditio.
\end{abstract}

Keywords: captatoria conditio, freedom of testation, testamentary conditions 


\section{Introduction}

It is the purpose of this paper to present and analyse the specific testamentary disposition known by the Latin name of captatoria conditio (and as kaptatorische Verfügung in German legal language). ${ }^{1}$ This form of disposition, being a particular type of conditional appointment to inheritance, is to a large extent permissible in German law, which is noteworthy since as a rule even in legal systems providing for conditional appointment to inheritance this particular type of condition is not allowed. This results from significant axiological doubts associated with captatoria conditio. The system of German law of succession presents itself as an exception as compared to other Western European legal orders. In Poland, in the current legal circumstances, captatoria conditio is not a subject matter of debate in scientific communities considering the general prohibition of appointing an heir under a condition that is in force in Poland. On the surface, it might seem that this issue presents no substantial value to Polish readers. However, one should bear in mind the proposals to introduce conditional appointment to inheritance to the Polish legal order that are sometimes made. ${ }^{2}$ In light of these de lege ferenda suggestions, the matter of captatoria conditio may become more important in the future. For this reason, it is worth taking a closer look at this legal measure and arguments in favour of its admissibility or the lack thereof.

\section{Captatoria conditio - characteristics as well as brief history and comparative legal analysis}

In general terms, it can be stated that a disposition captatoria is such a disposition upon death, by means of which the testator wishes to influence the last will of his heir and induce him to make a specific disposition mortis causa. Sometimes, such disposition is defined more narrowly, where it is accepted that it involves making a disposition under the condition that an heir makes his own disposition for the benefit of the testator himself or for a third party. ${ }^{3}$ Others perceive such disposition

1 The Latin name of captatoria conditio may be used in relation to dispositions captatoria present in various legal systems. On the other hand, the term kaptatorische Verfügung originates from German legal language and means captatoria conditio under German law. This paper will use those terms as defined above.

2 See e.g. Osajda, K., Ustanowienie spadkobiercy de lege ferenda, "Studia Prawa Prywatnego" 2009, Vol. 1, pp. 89-91.

3 Azaustre Fernández, M.J., Captación de voluntad en los testamentos y 'prohibición de confesores' de Roma a la actualidad, "Glossae. European Journal of Legal History" 2017, No. 14, p. 79. 
as appointment to inheritance under the condition that the heir or a third party appoints the testator as heir. ${ }^{4}$ In such case, the purpose of this disposition is to influence not only the last will of the heir but also the last will of a third party who is in a sense 'external' to the disposition. The aforementioned differences notwithstanding, the essence of captatoria conditio can be found in conditional appointment to inheritance (and thus mutual wills are not included in this category of dispositions ${ }^{5}$ ) and in influence exercised on the last will of another person (either the heir or a third party) by forming such condition in a particular way. The latter characteristic is associated with the name - a shameful one - of this disposition upon death: the Latin word captatoria is the feminine form of Lat. captatorius, meaning 'a hunter' - in this case, a hunter of inheritance.

In Roman law, such dispositions upon death were strictly prohibited, although - as has been indicated - they did not have to constitute by themselves an abuse of testamentary freedom. The principal argument in favour of impermissibility of dispositions captatoria was the heir's testamentary freedom. Irrespective of the testator's motives, captatoria conditio was therefore deemed a priori a prohibited action aimed at 'obtaining a will' of the heir for the benefit of the testator. ${ }^{6}$ Any condition that was expressed in this form was deemed non-existent. It is dubious, however, whether the testator that stipulated captatoria conditio was to be considered unworthy of succeeding after the person he appointed to inheritance (of course, if the person appointed to inheritance died at an earlier date and appointed the testator as his own heir in accordance with captatoria conditio). Also, the matter of validity of a disposition made for the testator's benefit, meeting the condition in form of captatoria conditio, has been the subject of discussions. ${ }^{7}$

The conviction, originating from the Roman law, about the unlawfulness of captatoria conditio has been reflected in the national civil law system of Spain and in the majority of civil law systems of the autonomous regions of Spain. ${ }^{8}$ Article 794

4 Cf. ibidem, pp. 79-80.

5 Ibidem, p. 80.

6 Ibidem, p. 80.

7 Ibidem, pp. 80-81.

8 The Spanish civil law system is very specific. There is a state-wide (national) civil law (Span. Derecho Común or Derecho Estatal). Independently of it, in territories of certain autonomous regions of Spain there are regional systems of civil law (Span. Derechos Forales). In the scope unregulated in regional law, the national law will be applicable. Regional systems of civil law are in force in Aragon, Catalonia, Valencia, Navarra, in the Basque Country, in Galicia and on the Balearic Islands. See in more detail in: Plaza Penadés, J., El Derecho Civil, los Derechos Civiles forales o especiales y el Derecho Civil autonómico, "Revista Electrónica de Derecho Civil Valenciano" 2012, No. 12, https://core.ac.uk/download/pdf/71025569.pdf (accessed 09.08.2020). Concerning the 
of the Spanish Civil Code ${ }^{9}$ says that a disposition made under a condition that the heir or the legatee makes a disposition for the benefit of the testator or a third party shall be invalid. As has been indicated in Spanish legal writings, the principal argument in favour of impermissibility of captatoria conditio is the personal nature of a will and the protection of testamentary freedom of the heir (legatee), which requires prohibiting any and all interferences with his last will. ${ }^{10}$ It has, however, been alleged that Article 794 of the Spanish Civil Code is obsolete since there are no reasons to prohibit captatoria conditio while stipulating certain other conditions may be equally or even more immoral. ${ }^{11}$ As it stands, the Spanish law prohibits captatoria conditio, additionally under a very harsh sanction: it results in invalidity of the entire disposition (and not in a legal fiction that the condition be deemed nonexistent). The severity of this sanction is justified by the forbidden and immoral nature of captatoria conditio. ${ }^{12}$

A similar solution to the one adopted in the national inheritance law of Spain can be found in Catalonian inheritance law. Article 423-19 of the Catalonian Civil Code ${ }^{13}$ states that dispositions captatoria result in invalidity of appointment of an heir. ${ }^{14} \mathrm{~A}$ regulation to the contrary, however, has been introduced in Aragon law - Article 476 of Aragon Regional Law Code ${ }^{15}$ provides for a general rule that all conditions that are not impossible nor contrary to the law or accepted principles

history of regional systems of civil law in autonomous regions of Spain, see: García Pérez, R., Derechos forales y Codificación civil en España (1808-1880), "Anuario de Historia del Derecho Español" 2012, No. 82, pp. 152-174; De Benito Fraile, E.J., La codificación civil y los derechos forales (18081833), "Cuadernos de Historia del Derecho" 2012, No. 19, pp. 65-97.

9 Spanish Civil Code of 24 July 1889, Gaceta de Madrid (Official Gazette of Madrid) of 25 July 1889, No. 206, as amended.

10 Quesada González, M.C., La institución de heredero sometida a condición, a término o a modo, Madrid 2018, pp. 94-95.

11 See opinions cited ibidem, p. 95.

12 Ibidem, p. 98. The author, however, holds that the testator may modify the voidness of the disposition so that, should it prove that the disposition has the characteristics of captatoria conditio as specified in Article 794 of the Spanish Civil Code, such appointment to inheritance (executing the legacy) should be deemed unconditional: ibidem.

13 Catalonian Civil Code, Law 10/2008 of Book 4 of the Civil Code of Catalonia relating to successions, of 10 July 2008, Diari Oficial de la Generalitat Catalunya (Official Gazette of the Government of Catalonia) of 17 July 2008, No. 5175, as amended.

14 See also: Bosch Capdevila, E., Testamentary freedom and its limits, in: Anderson, M. and Arroyo i Amayuelas, E. (eds.), The law of succession: testamentary freedom. European perspectives, Groningen 2011, pp. 80-81.

15 Aragon Regional Law Code of 22 March 2011, BOA (Official Bulletin of Aragon) of 29 March 2011, No. 67, as amended. 
of morality shall be valid. Further, this provision contains examples of permitted (valid) conditions, including a condition where an heir or a legatee shall make a disposition mortis causa for the benefit of the testator or a third party. As has been indicated by M.C. Quesada González, the starting point of the Aragon solution was the view that prohibitions of captatoria conditio were of archaic nature. ${ }^{16}$ Further, in her opinion this solution demonstrates coherence of Aragon inheritance law, where inheritance contracts and joint wills are allowed ${ }^{17}$ (i.e. legal measures whose essence lies in - at least to a certain extent -'binding' the last will of disposing parties; it should be noted that in the case of inheritance contracts and joint wills a disposing party actively expresses willingness to bind his last will with the last will of another person by making a relevant legal act (i.e. by executing an inheritance contract or making a joint will), while in the case of captatoria conditio the last will is 'captured' without the participation of a disposing party and only based on a disposition mortis causa of his testator). Inheritance law systems of other autonomous regions of Spain do not contain any provisions relating to captatoria conditio. ${ }^{18}$ In accordance with the rule specified in the third sentence of Article 149(3) of the Spanish Constitution ${ }^{19}$, national law is complementary in relation to regional legal systems - in matters not regulated in regional provisions, national provisions of law shall be applicable. ${ }^{20}$ This means that in those regional systems where captatoria conditio is not regulated, Article 794 of the Spanish Civil Code as well as resulting prohibition of making such dispositions mortis causa will apply.

Captatoria conditio is also prohibited in Italian law. Article 635 of the Italian Civil Code ${ }^{21}$ bans any universal and specific dispositions mortis causa subject to a condition of a reciprocated disposition upon death for the benefit of the testator (this is where the expression 'condition of reciprocity', It. condizione di reciprocità,

16 Quesada González, M.C., op. cit. p. 95.

17 Ibidem, p. 100.

18 Cf. De Amunátegui Rodríguez, C. et al., Código civil concordado con la legislación de las Comunidades Autónomas de Galicia, País Vasco, Navarra, Aragón, Cataluña y Baleares, Madrid 2008, p. 520 .

19 Constitution of Spain of 31 October 1978, BOE (Official State Gazette) of 29 December 1978, No. 311, as amended.

20 García Rubio, M.P., Plurilegislación, supletoriedad y derecho civil, in: González Porras, J.M. and Méndez González, F.P. (eds.), Libro homenaje al profesor Manuel Albaladejo García. Tomo I, Murcia 2004, p. 1940.

21 Italian Civil Code, Royal Decree No. 262 of 16 March 1942, Gazzetta Ufficiale Serie Generale (Official Gazette General Series) of 4 April 1942, No. 79, as amended. 
comes from).$^{22}$ Making such disposition results in, analogically to Spanish law, complete invalidity thereof (and not merely in a legal fiction that the condition be deemed non-existent). The Italian legislator considers conditions of this type to constitute a 'deceitful suppression' of freedom of testation on the part of a beneficiary of dispositions. ${ }^{23}$ Interestingly, this provision does not apply to dispositions made under the condition of making a disposition mortis causa for the benefit of a third party indicated by the testator. This does not mean, however, that this form of captatoria conditio is allowed in the Italian law. In such case, the condition is still not permitted but is instead deemed non-existent (benefit upon death, however, is valid and effective). ${ }^{24}$

A completely different approach to the permissibility of captatoria conditio is presented in the German inheritance law. $\mathrm{BGB}^{25}$ does not specifically mention this particular type of disposition upon death. In light of this absence of an expressed prohibition of such dispositions mortis causa, it may be questionable if such dispositions are permitted on the basis of accepted principles of morality $-\S 138$ BGB provides for invalidity of legal transactions contrary to accepted principles of morality and is applicable also to last will dispositions. ${ }^{26}$ In the German legal scholarship, however, it is commonly accepted that captatoria conditio is as a rule permitted to a large extent. It is considered that a testator may subject a disposition mortis causa to a condition that the beneficiary makes certain dispositions upon death. ${ }^{27} \mathrm{D}$. Weidlich expresses kaptatorische Verfügung more narrowly, stating that a condition of making the testator or a third party the heir is permitted. ${ }^{28}$ Such an approach leads to the question of permissibility of appointment to inheritance under a condition of, for example, disinheriting a certain person. It has been emphasized of course that kaptatorische Verfügung does not violate the prohibition of accepting the obligation to execute a will, as provided for in $₫ 2302$ of BGB, since

22 Cf. Sesta, M., Codice delle successioni e donazioni. Volume I. Costituzione e Quattro Codici, Milano 2011, p. 1343.

23 Ibidem.

24 Ibidem, p. 1344.

25 German Civil Code of 18 August 1896, BGBl. (Federal law Gazette) I, p. 42, 2909; 2003 I, p. 738, as amended.

26 Ellenberger, J., $\$$ 138, in: Palandt, Bürgerliches Gesetzbuch, München 2017, p. 139, section number 11 .

27 Leipold, D., \$2074, in: Kessal-Wulf, S. (ed.), Münchener Kommentar zum BGB. Band 11. Erbrecht, München 2020, section number 17; Litzenburger, W., \$ 2074, in: Bamberger, H.G. et al., Beck'scher Online-Kommentar BGB, München 2020, section number 19.

28 Weidlich, D., \$2074, in: Palandt, Bürgerliches Gesetzbuch, München 2018, p. 2424, section number 5 . 
the beneficiary of such disposition is under no obligation to fulfil such condition. ${ }^{29}$ The German legal commentary does not consider at length whether captatoria conditio interferes with heir's freedom of testation, although it has been observed that when analysed from this perspective captatoria conditio becomes 'problematic.'30

\section{Functions of captatoria conditio and related axiological doubts}

Functions that captatoria conditio may serve are strictly related to general objectives of a conditional appointment to inheritance. The main purpose of stipulating a condition in appointing an heir is ensuring that the future of the estate can be specified in full accordance with the testator's intent. ${ }^{31}$ The testator may in a better - in his opinion - way determine the fate of the estate after he has died, and thus to adjust it to the circumstances of his specific situation. ${ }^{32}$ This is one of the most important functions of freedom of testation in general. However, a condition may also constitute a mechanism by means of which the testator wishes not such much to properly determine the legal succession in the event of death but rather to put pressure on behaviours of other people or even - to put it more strongly - to force them to take certain actions by exerting economic pressure in the form of making dispositions mortis causa dependent on fulfilling a condition. This may involve a variety of potestative conditions which - in legal systems permitting conditional appointment to inheritance - are usually examined in terms of their correspondence to principles of life in community (acceptance principles of morality) if they pertain to strictly personal matters of the beneficiary. ${ }^{33}$ In such case, the will becomes a transaction of sorts, entailing the exchange of certain values: appointment to inheritance (or alternatively other disposition mortis causa) in exchange for a scenario desired by the testator. Undoubtedly, having the option

29 Leipold, D., op. cit., section number 17.

30 Blomberg, E.M., Freiheit und Bindung des Erblassers. Eine Untersuchung erbrechtlicher Verwirklichungsklauseln, Tübingen 2011, p. 8.

31 Cf. Niezbecka, E., Ustanowienie spadkobiercy i zapisobiorcy w testamencie, "Rejent" 1992, No. 6, p. 45.

32 Lenz, N., \$ 2074, in: Hau, W. (ed.), Juris Praxiskommentar BGB. Erbrecht. Band 5, Saarbrücken 2007, p. 594, section number 27.

33 This is discussed in more detail in: Lange, H. and Kuchinke, K., Erbrecht, München 2001, pp. 827828; Lenz, N., op. cit., p. 594, section numbers 27-28; Dittrich, L., Verfassungsrechtliche Vorgaben des Erbrechts, "Zeitschrift für Erbrecht und Vermögensnachfolge" 2013, Vol. 1, p. 19; Leipold, D., op. cit., section number 25; Vaquer Aloy, A., Libertad de testar y condiciones testamentarias, "InDret" 2015, No. 3, pp. 11-14. 
to appoint an heir under a condition enhances the freedom of testation since it increases the number of possibilities by which the testator is able to determine legal succession in the event of death.

Stipulating such a particular condition as captatoria conditio fulfils all of the aforementioned functions, but does it so more strongly than any other type of condition. It is the substance of captatoria conditio to determine the fate of the estate not only in the event of and after the testator's death, but also in the event of and after the death of the heir. Captatoria conditio is, for this reason, an interesting example of an internal conflict existing within the freedom of testation principle: conflict between testator's freedom of testation and heir's freedom of testation. ${ }^{34}$ Taking this into account, we should note that one of the principal problems related to freedom of testation as such is the fact that it will always collide in a certain degree with the autonomy of will of the other parties. Intrinsically, freedom of testation enables the testator to make decisions in matters that by their very nature do not concern him, but involve only persons that remain alive. This is related to the problem of the so-called dead hand grip or dead hand control (German: Herrschaft der kalten (toten) Hand or Herrschaft aus dem Grabe) ${ }^{35}$, where pressure is exerted on living persons via dispositions mortis causa and decisions are made that would bind those persons for many years to come. ${ }^{36}$ This iron grip of a dead hand is, as a rule, not acceptable. It has been indicated therefore that freedom of testation should end where the influence of a deceased person on the living world becomes too strong. This is the case both when this influence is too intense (expressive pressure on life,

34 In this respect, one can see the similarities between captatoria conditio and fiduciary substitution, where the heir is under the obligation to give the inherited property to a specific person following the heir's death. However, fiduciary substitution is more limited in its scope, since it only applies to inherited property, while captatoria conditio can entail the establishment of universal legal succession, i.e. not only in relation to inherited property but to the entire property of the heir.

35 About the meaning of those terms in the light of language-based image of the world, see: Owsiński, P.A. and Paluch, A., Zum sprachlichen Weltbild in ausgewählten Begriffen aus dem Bereich des Erbrechts in der deutschen und polnischen Sprache, "Colloquia Germanica Stetinensia" 2020, No. 29, pp. 270-271.

36 This is discussed in more detail in: Longchamps de Bérier, F., Ręka zza grobu? Wokół granic dysponowania majątkiem na wypadek śmierci w prawie rzymskim, in: Grodziski, S. et al. (eds.), Vetera novis augere. Studia i prace dedykowane Profesorowi Wacławowi Uruszczakowi, Tom I, Kraków 2010, p. 611; Wilke, U., Willensherrschaft und Nachlassbindung, Frankfurt am Main 2017, pp. 22, 23; Schlüter, W., Grenzen der Testierfreiheit - Grenzen einer "Herrschaft aus dem Grabe", in: Hadding, W. (ed.), Festgabe Zivilrechtslehrer 1934/1935, Berlin-New York 1999, p. 575; Hirsch, A.J. and Wang, W.K.S., A qualitative theory of the dead hand, "Indiana Law Journal" 1992, Vol. 68, pp. 3, 22. 
in particular personal life, of other people) and when it is too extensive (making decisions about the fate of many following generations). ${ }^{37}$

In consideration of the discussion carried out above, appointment to inheritance whilst stipulating captatoria conditio may seem as having too extensive impact on post mortem reality (and if we consider the freedom of testation as one of the most important aspects of autonomy of will afforded to human beings - and in my opinion there are valid reasons therefor - as too intense as well). Exactly those reasons lie, in all likelihood, at the root of the conviction that dispositions captatoria are immoral.

However, a conviction about the excessive pressure of the dead hand grip should not be shared too rashly. It is justified to ask whether, in light of the fact that in all contemporary legal systems the heir is afforded the option to reject inheritance, there is any pressure exerted on the heir in connection with the condition stipulated by the testator. I. Kroppenberg indicates that the motif of the dead hand was grounded on an unreasonable belief that there is no control over testator's dispositions, which would lead to his unlimited power. In her opinion, however, the option to reject inheritance is precisely such a method of control. In the case of conditional dispositions, rejecting inheritance boils down to 'rejecting the scenario written by the testator', which the heir is always allowed to do.$^{38}$ As Kroppenberg concludes: 'if the living world falls into chaos as a result of dispositions upon death, this happens in the first place not because the dead have the power but because the living allow it' (author's own translation).$^{39}$ So, it is the living who have the final word in the matter. Since therefore the problem of the testator's exerting any pressure on beneficiaries of dispositions does not exist, there can be no excessive grip that a conditional appointment to inheritance has over the fate of the living. The justification of captatoria conditio prohibition no longer has any merit. If for the heir 'binding' his last will and making dispositions concerning his estate according to instructions received from the testator is too much of a burden, the heir is free to reject inheritance and retain full freedom of testation. If, however, he accepts the inheritance, he agrees to fulfil the condition. One way or another, he acts within the confines of autonomy of will that is afforded to him.

There are several reservations asserted against such view of conditional appointment to inheritance, which, however, as it seems, do not apply to captatoria conditio.

37 Cf. Hirsch, A.J. and Wang, W.K.S., op. cit., pp. 16-17.

38 Kroppenberg, I., 'Wer lebt, hat Recht' - Lebzeitiges Rechtsdenken als Fremdkörper in der Inhaltskontrolle von Verfügungen von Todes wegen, "Deutsche Notar-Zeitschrift" 2006, Vol. 2, pp. 101-105.

39 Ibidem, p. 105. 
For instance, G. Otte indicates that there are situations where the testator, while alive, prepares his children to take over his estate (e.g. by giving them a proper education so that they could inherit the business). If thereafter he appoints his children to inheritance under a condition relating to their strictly personal life, the choice to either accept the inheritance and fulfil the condition or to reject the inheritance becomes a very difficult life decision. ${ }^{40}$ These reservations do not concern this particular condition of captatoria conditio as it does not affect the heir's life but only his dispositions upon death.

Of course, exercise of freedom of testation is a deeply personal experience, in which both the final decision about the fate of someone's possessions and the final expression of feelings towards the living as well as opinions about their behaviour and life attitude are expressed. By fulfilling a captatoria conditio, the testator is deprived of all of this - his last will is, in a manner of speaking, 'seized' by his testator, and the disposition mortis causa becomes an expression of not his last will but of that of his testator. In this case it is the exercise of the testator's freedom of testation that is of utmost importance. This is a primary axiological problem associated with dispositions captatoria. One should not, however, lose sight of the circumstances to which Kroppenberg points - namely, the fact that the decision on whether to accept the inheritance and fulfil the condition lies with the heir. If such decision is made, he accepts the testator's will, and thus the testator's will becomes - at least to a certain extent - his own will. Therefore, there are, I believe, no convincing reasons for prohibiting captatoria conditio in legal systems that permit conditional appointment to inheritance.

\section{Conclusions}

The majority of the discussed Western European legislations that allow for a conditional appointment of an heir provide for the prohibition of appointment to inheritance under the specific condition of captatoria conditio. The only exceptions can be found in the inheritance law of Germany and Aragon. Justifications of prohibiting captatoria conditio are of axiological nature. Axiological doubts are raised by the fact that this form of condition leads to restricting the heir's freedom of testation. On the surface, it might seem that captatoria conditio highly limits his autonomy of will, but in principle it is not an expression of excessive influence of

40 Otte, G. (ed.), J. von Staudingers Kommentar zum Bürgerlichen Gesetzbuch mit Einführungsgesetz und Nebengesetzen. Buch 5. Erbrecht. $\$ \$ \$$ 2064-2196 (Testament 1), Berlin 2003, pp. 136-137, sections number 31a-31b. 
the testator on the fate of the living nor does it constitute an abuse of freedom of testation. The heir has the option to reject the inheritance after all: he may either accept the inheritance and fulfil the condition or reject the inheritance and retain full freedom of testation. For this reason, pressure put on an heir is not really bigger than in the case of other types of conditions. In extraordinary situations, the last line of defence of the heir's freedom can be the evaluation of the disposition in terms of compliance with accepted principles of morality should such a clause be featured in a given legal system (for example, if the condition includes leaving out of the heir's will a person in a difficult financial situation or in poor health). Therefore, there are no convincing reasons for prohibiting this specific condition which is captatoria conditio.

\section{References}

Azaustre Fernández, M.J., Captación de voluntad en los testamentos y 'prohibición de confesores' de Roma a la actualidad, "Glossae. European Journal of Legal History 2017", No. 14.

Blomberg, E.M., Freiheit und Bindung des Erblassers. Eine Untersuchung erbrechtlicher Verwirklichungsklauseln, Tübingen 2011.

Bosch Capdevila, E., Testamentary freedom and its limits, in: Anderson, M. and Arroyo i Amayuelas, E. (eds.), The law of succession: testamentary freedom. European perspectives, Groningen 2011.

De Amunátegui Rodríguez, C. et al., Código civil concordado con la legislación de las Comunidades Autónomas de Galicia, País Vasco, Navarra, Aragón, Cataluña y Baleares, Madrid 2008.

De Benito Fraile, E.J., La codificación civil y los derechos forales (1808-1833), "Cuadernos de Historia del Derecho" 2012, No. 19.

Dittrich, L., Verfassungsrechtliche Vorgaben des Erbrechts, "Zeitschrift für Erbrecht und Vermögensnachfolge" 2013, Vol. 1.

Ellenberger, J., \$138, in: Palandt, Bürgerliches Gesetzbuch, München 2017.

García Pérez, R., Derechos forales y Codificación civil en España (1808-1880), "Anuario de Historia del Derecho Español" 2012, No. 82.

García Rubio, M.P., Plurilegislación, supletoriedad y derecho civil, in: González Porras, J.M. and Méndez González, F.P. (eds.), Libro homenaje al profesor Manuel Albaladejo García. Tomo I, Murcia 2004.

Hirsch, A.J. and Wang, W.K.S., A qualitative theory of the dead hand, "Indiana Law Journal" 1992, Vol. 68. 
Kroppenberg, I., "Wer lebt, hat Recht" - Lebzeitiges Rechtsdenken als Fremdkörper in der Inhaltskontrolle von Verfügungen von Todes wegen, "Deutsche Notar-Zeitschrift" 2006, Vol. 2.

Lange, H. and Kuchinke, K., Erbrecht, München 2001.

Leipold, D., \$ 2074, in: Kessal-Wulf, S. (ed.), Münchener Kommentar zum BGB. Band 11. Erbrecht. München 2020.

Lenz, N., \$ 2074, in: Hau, W. (ed.), Juris Praxiskommentar BGB. Erbrecht. Band 5, Saarbrücken 2007.

Litzenburger, W., $\$$ 2074, in: Bamberger, H.G. et al., Beck'scher Online-Kommentar BGB, München 2020.

Longchamps de Bérier, F., Ręka zza grobu? Wokół granic dysponowania majątkiem na wypadek śmierci w prawie rzymskim, in: Grodziski, S. et al. (eds.), Vetera novis augere. Studia i prace dedykowane Profesorowi Wacławowi Uruszczakowi, Tom I, Kraków 2010.

Niezbecka, E., Ustanowienie spadkobiercy $i$ zapisobiorcy $w$ testamencie, "Rejent" 1992, No. 6.

Osajda, K., Ustanowienie spadkobiercy de lege ferenda, "Studia Prawa Prywatnego" 2009, Vol. 1.

Otte, G., in: Otte, G. (ed.), J. von Staudingers Kommentar zum Bürgerlichen Gesetzbuch mit Einführungsgesetz und Nebengesetzen. Buch 5. Erbrecht. \$\$ 2064-2196 (Testament 1), Berlin 2003.

Owsiński, P.A. and Paluch, A., Zum sprachlichen Weltbild in ausgewählten Begriffen aus dem Bereich des Erbrechts in der deutschen und polnischen Sprache, "Colloquia Germanica Stetinensia" 2020, No. 29.

Plaza Penadés, J., El Derecho Civil, los Derechos Civiles forales o especiales y el Derecho Civil autonómico, "Revista Electrónica de Derecho Civil Valenciano" 2012, No. 12, https://core.ac.uk/download/pdf/71025569.pdf.

Quesada González, M.C., La institución de heredero sometida a condición, a término o a modo, Madrid 2018.

Schlüter, W., Grenzen der Testierfreiheit - Grenzen einer "Herrschaft aus dem Grabe", in: Hadding, W. (ed.), Festgabe Zivilrechtslehrer 1934/1935, Berlin-New York 1999.

Sesta, M., Codice delle successioni e donazioni. Volume I. Costituzione e Quattro Codici, Milano 2011.

Vaquer Aloy, A., Libertad de testar y condiciones testamentarias, "InDret” 2015, No. 3.

Weidlich, D., \$2074, in: Palandt, Bürgerliches Gesetzbuch, München 2018.

Wilke, U., Willensherrschaft und Nachlassbindung, Frankfurt am Main 2017. 


\section{CITATION}

Paluch, A., Captatoria conditio: meaning and admissibility in the light of freedom of testation. Analysis of selected legislations of Western European countries, "Acta Iuris Stetinensis" 2020, No. 4 (Vol. 32), 51-63, DOI: 10.18276/ais.2020.32-04. 